\title{
Microwave-Assisted Solid-Liquid Phase Alkylation of Naphthols
}

\author{
Erika Bálint ${ }^{1}$, Orsolya Kovács ${ }^{2}$, László Drahos $^{3}$ and György Keglevich ${ }^{2, *}$
}

\begin{abstract}
${ }^{1}$ Research Group of the Hungarian Academy of Sciences at the Department of Organic Chemistry and Technology, Budapest University of Technology and Economics, 1521 Budapest, Hungary; ${ }^{2}$ Department of Organic Chemistry and Technology, Budapest University of Technology and Economics, 1521 Budapest, Hungary; ${ }^{3}$ Hungarian Academy of Sciences, Chemical Research Center, 1525 Budapest, Hungary
\end{abstract}

Received January 31, 2013: Revised March 08, 2013: Accepted March 16, 2013

\begin{abstract}
The microwave promoted alkylation of 1- and 2-naphthols with benzyl, butyl, ethyl and isopropyl halides in the presence of an alkali carbonate may result in $O$ - and $C$-alkylated products. The alkylations were $O$-selective in the presence of $\mathrm{K}_{2} \mathrm{CO}_{3}$ in acetonitrile as the solvent and in the absence of phase transfer catalyst. The alkylations utilizing butyl and ethyl halides were also $O$-selective in solventless accomplishment and in the presence of triethylbenzylammonium chloride.
\end{abstract}

Keywords: $O$-alkylation, $C$-alkylation, microwave, phase transfer catalyst.

\section{INTRODUCTION}

The phase transfer (PT) catalytic and microwave (MW) techniques are widespread tools in modern environmentally friendly chemistry. Combination of these two techniques was a logical extension $[1,2]$. In certain cases, MW irradiation may substitute the PT catalyst. It was found that the MWassisted solid-liquid (S-L) PT catalytic alkylation of $\mathrm{CH}$ acidic substrates could be carried out in the absence of any catalyst, moreover in a solvent-free accomplishment $[3,4]$. In $N$-alkylations, the role of PT catalyst and MW irradiation is more complicated [5]. In this paper we concentrate on the role of MW and PT catalysis in $O$-alkylations, namely in the alkylation of naphthols.

The PT catalytic technique was applied widely in the alkylation of phenol derivatives. A part of the reactions was carried out in S-L phase using solvents and alkali hydroxides as the base $[6,7]$. Solvent-free alkylations accomplished in the presence of $\mathrm{K}_{2} \mathrm{CO}_{3}$ or $\mathrm{K}_{2} \mathrm{CO}_{3} / \mathrm{NaOH}$ were also described $[8,9]$. In one case, sodium phenolate formed the solid phase [10], while, in another instance, a liquid-liquid (L-L) phase alkylation applying aqueous $\mathrm{NaOH}$ was utilized [11]. In the latter two instances, toluene was the solvent. It is worthy to mention that a few $O$-alkylations were carried out in the absence of any PT catalyst. In these cases $\mathrm{K}_{2} \mathrm{CO}_{3}$ was used in acetone [12] or in methanol [13]. Another catalyst-free accomplishment was possible, when a combined MW and ultrasound irradiation enhanced the L-L phase alkylation [14]. The Keglevich group found that the PT catalytic alkylation of phenols may be synergistically enhanced by MW irradiation $[15,16]$. In the MW-assisted alkylation of phenols, the application of quaternary ammonium salts as the

\footnotetext{
*Address correspondence to this author at the Department of Organic Chemistry and Technology, Budapest University of Technology and Economics, 1521 Budapest, Hungary; Tel: +36-1-463-1111(5883); Fax: +36-1463-3648; E-mail: gkeglevich@mail.bme.hu
}

alkylating agent proved to be useful due to the good energy absorbing ability of these polar species [17].

Literature precedents for the alkylation of 1- and 2naphthols (1) and (6) (and other derivatives) are summarized in Table 1. In general, alkyl halides were the reactants and alkali carbonates or alkali hydroxides were the bases. In the first three cases, the alkylations were carried out using $\mathrm{K}_{2} \mathrm{CO}_{3} /$ acetone or $\mathrm{Cs}_{2} \mathrm{CO}_{3} / \mathrm{MeCN}$ systems. The yields varied in the range of 39-98\% (Table $1 /$ Entries 1-3) [18-20]. 2Naphthol (6) was benzylated using a $\mathrm{NaOH} / \mathrm{PhMe}$ system and a PT catalyst. The yield was $80 \%$ (Table $1 /$ Entry 4) [21]. The sodium salt of 2-naphthol (6) was alkylated using $\mathrm{Me}_{2} \mathrm{SO}_{4}$ and $\mathrm{Al}_{2} \mathrm{O}_{3} / \mathrm{EtOH}$, but this accomplishment was quite slow (Table 1 / Entry 5) [22]. Other PT catalytic versions of the alkylation of naphthols led, in most cases, to low yields (13-50\%) (Table 1/ Entries 6-8) [23-25]. The first MWassisted alkylation of naphthols was performed in the presence of $\mathrm{Cu} / \mathrm{CuCl}_{2}$ providing the alkylated products in variable yields (Table 1 / Entry 9) [26]. The MW-assisted SL PT catalytic benzylation of 2-naphthol (6) was carried out in the presence of $\mathrm{NaOH}$ as the base, in the absence of any solvent. The yield of 2-benzyloxynaphthalene (7) was $92 \%$ (Table 1 / Entry 10) [27]. The alkylation of naphthols was also described using alkali hydroxides in ionic liquids (Table $1 /$ Entries 11 and 12) [28, 29]. In a special procedure, the naphthols were alkylated with alcohols in the presence of boron trifluoride etherate (Table 1/ Entry 13) [30]. Naphthols were also alkylated by quaternary onium salts [31, 32]. This method is especially noteworthy under MW conditions due to the special energy absorbing ability of the onium salt [32]. According to a special method alkylated naphthols were prepared by the oxidative-reductive condensations of phenols and alcohols [33].

It was a challenge for us to study the MW-assisted alkylation of naphthols in the presence or absence of a PT catalyst and solvent. 
Table 1. Alkylation of Naphthols Using Common Alkylating Agents

\begin{tabular}{|c|c|c|c|c|c|c|c|c|}
\hline Naphthol & Alkylating Agent & Base & PTC & Solvent & $\mathbf{T}, \mathbf{t}$ & Yield (\%) & Ref. & Entry \\
\hline 1-naphthol (1) & $\mathrm{BnBr}$ & $\mathrm{K}_{2} \mathrm{CO}_{3}$ & - & acetone & $\Delta, 10 \mathrm{~h}$ & 78 & [18] & 1 \\
\hline 2-naphthol (6) & $\begin{array}{c}\mathrm{MeI}, \mathrm{BnBr}, \\
\mathrm{CH}_{2}=\mathrm{CHCH}_{2} \mathrm{Br}\end{array}$ & $\mathrm{Cs}_{2} \mathrm{CO}_{3}$ & - & $\mathrm{MeCN}$ & $\Delta, 4-5 \mathrm{~h}$ & $91-98$ & [19] & 2 \\
\hline 2,7-dihydroxynaphthalene & $\mathrm{BnBr}$ & $\mathrm{K}_{2} \mathrm{CO}_{3}$ & - & acetone & $25^{\circ} \mathrm{C}, 4 \mathrm{~h}$ & 39 & {$[20]$} & 3 \\
\hline 2-naphthol (6) & $\mathrm{BnBr}$ & $\mathrm{NaOH}$ & TEBAC & $\mathrm{PhMe}$ & $90^{\circ} \mathrm{C}, 1 \mathrm{~h}$ & 80 & [21] & 4 \\
\hline Na salt of 2-naphthol (6) & $\mathrm{Me}_{2} \mathrm{SO}_{4}$ & $\mathrm{Al}_{2} \mathrm{O}_{3}$ & - & $\mathrm{EtOH}$ & $50^{\circ} \mathrm{C}, 2$ days & 98 & [22] & 5 \\
\hline 2-naphthol (6) & $\mathrm{BnBr}$ & $\mathrm{NaOH}$ & PTC $^{\mathrm{a}}$ & $\mathrm{PhMe} / \mathrm{H}_{2} \mathrm{O}$ & $55^{\circ} \mathrm{C}, 18 \mathrm{~h}$ & 33,50 & [23] & 6 \\
\hline 2-naphthol (6) & $\mathrm{BnCl}$ & with PTC m & fied bentonite $^{b}$ & petroleum ether & $25^{\circ} \mathrm{C}, 15 \mathrm{~h}$ & 36 & [24] & 7 \\
\hline $\begin{array}{l}\text { 1- and 2-naphthol (1) } \\
\text { and (6) }\end{array}$ & $\mathrm{BnBr}$ & $\mathrm{Cs}_{2} \mathrm{CO}_{3}$ & $\begin{array}{c}\text { calix }[4] \text { pyrrole } \\
\text { derivative }\end{array}$ & $\mathrm{CD}_{3} \mathrm{CN}, \mathrm{CH}_{3} \mathrm{CN}$ & $40{ }^{\circ} \mathrm{C}$ & 87,13 & [25] & 8 \\
\hline $\begin{array}{l}\text { 1- and 2-naphthol (1) } \\
\text { and (6) }\end{array}$ & $\begin{array}{c}\mathrm{BnCl}, \mathrm{BnBr} \\
\mathrm{BrCH}_{2} \mathrm{CH}=\mathrm{CH}_{2}\end{array}$ & - & $\mathrm{Cu} / \mathrm{CuCl}_{2}$ & - & $\mathrm{MW}, 1,5-2 \mathrm{~min}$ & $61-90$ & {$[26]$} & 9 \\
\hline 2-naphthol (6) & $\mathrm{BnCl}$ & $\mathrm{NaOH}$ & TBAB & - & $\mathrm{MW}, 90^{\circ} \mathrm{C}, 3 \mathrm{~h}$ & 92 & [27] & 10 \\
\hline 1-substituted 2-naphthol ${ }^{\mathrm{c}}$ & EtI, BuBr, MeI, BnBr & $\mathrm{KOH}$ & - & $\begin{array}{l}{[\mathrm{bmim}]\left[\mathrm{PF}_{6}\right],} \\
{[\mathrm{bmim}]\left[\mathrm{PF}_{4}\right]}\end{array}$ & $20^{\circ} \mathrm{C}, 2-3 \mathrm{~h}$ & $94-98$ & [28] & 11 \\
\hline 2-naphthol (6) & $\mathrm{MeI}, \mathrm{EtBr}, \mathrm{BnCl}$ & $\mathrm{NaOH}$ & - & $\begin{array}{c}{[\mathrm{bdmim}]\left[\mathrm{PF}_{6}\right],} \\
{[\mathrm{bmim}]\left[\mathrm{PF}_{6}\right]}\end{array}$ & $25^{\circ} \mathrm{C}, 2 \mathrm{~h}$ & $93-97$ & [29] & 12 \\
\hline $\begin{array}{l}\text { 1- and 2-naphthol (1) } \\
\text { and (6) }\end{array}$ & $\begin{array}{c}\mathrm{EtOH}, \mathrm{PrOH},{ }^{i} \mathrm{PrOH}, \\
\mathrm{BuOH},{ }^{n} \mathrm{C}_{8} \mathrm{H}_{17} \mathrm{OH}, \\
{ }^{i} \mathrm{C}_{8} \mathrm{H}_{17} \mathrm{OH}\end{array}$ & \multicolumn{2}{|c|}{$\mathrm{BF}_{3} \cdot \mathrm{OEt}_{2}$} & - & $80^{\circ} \mathrm{C}, 15 \mathrm{~h}$ & $54-85$ & {$[30]$} & 13 \\
\hline
\end{tabular}

PTC: $\mathrm{P}-\mathrm{CH}_{2} \mathrm{P}^{+} \mathrm{Bu}_{3} \mathrm{Cl}^{-}$

${ }^{b}$ With 1-Cetyl-4-aza-1-azonia bicyclo[2.2.2] octane chloride modified bentonite $\left(\mathrm{SiO}_{2}(65.04 \%), \mathrm{Fe}_{2} \mathrm{O}_{3}(1.67 \%), \mathrm{MgO}(1.87 \%), \mathrm{Al}_{2} \mathrm{O}_{3}(13.61 \%), \mathrm{CaO}_{(2.01 \%)}\right.$, TiO 2 (0.19\%), $\mathrm{Na} 2 \mathrm{O}$ $(2.26 \%), \mathrm{K}_{2} \mathrm{O}(0.75 \%)$

'Substituent: $\mathrm{H}, \mathrm{Me}, \mathrm{Et}, \mathrm{Bu}, \mathrm{Bn}$.

\section{RESULTS AND DISCUSSION}

The first model reaction was the alkylation of 1-naphthol (1) with benzyl bromide at $125{ }^{\circ} \mathrm{C}$ for $1 \mathrm{~h}$ under $\mathrm{MW}$ and solvent-free conditions (Scheme 1, Table 2). In the absence of $\mathrm{K}_{2} \mathrm{CO}_{3}$ and $\mathrm{PT}$ catalyst (TEBAC $=$ triethylbenzylammonium chloride), the conversion was $87 \%$, but no $O$ benzylated product 2 was formed. Instead, 4-benzyl-1naphthol (3) and 2-benzyl-1-naphthol (4) were obtained in $28 \%$ and $26 \%$, respectively. $33 \%$ of dialkylated products (marked as 5) were also present in the mixture that were not identified beyond GC-MS spectra (Table 2 / Entry 1). It can be seen that, in the absence of base, the benzylation is $C$ selective. Repeating the benzylation in the presence of 1 equivalent of $\mathrm{K}_{2} \mathrm{CO}_{3}$, the conversion was $81 \%$ and the reaction remained $C$-selective affording the 4-benzyl-1-naphthol (3) as the predominating product $(61 \%)$. The proportion of the desired $O$-benzyl product 2 was only 3\% (Table 2 / Entry 2 ). Adding also $5 \mathrm{~mol} \%$ of TEBAC to the reactants before irradiation, surprisingly, a $40-14-22 \%$ mixture of products $\mathbf{3}, \mathbf{4}$, and $\mathbf{5}$, respectively, was obtained. No $O$-alkylation to give compound $\mathbf{2}$ occurred (Table 2 / Entry 3). Better results were obtained when $\mathrm{Cs}_{2} \mathrm{CO}_{3}$ was used instead of $\mathrm{K}_{2} \mathrm{CO}_{3}$. In the absence of catalyst, products 2 , $\mathbf{3}$, and $\mathbf{5}$ were obtained in $62 \%, 16 \%$ and $13 \%$, respectively
(Table 2 / Entry 4). In the presence of TEBAC, the conversion remained the same (ca $90 \%$ ), but the ratio of products $\mathbf{2}$, 3, and 5 was $68 \%, 5 \%$ and $13 \%$ (Table $2 /$ Entry 5). Under solvent-free accomplishment, the maximum proportion of the $O$-alkylated product 2 was $68 \%$. It can be that in the absence of solvent, no satisfactory $O$-selectivity could be achieved. However, carrying out the benzylation in acetonitrile at $125{ }^{\circ} \mathrm{C}$ for $20 \mathrm{~min}$ (in a closed vial), the 1benzyloxynaphthalene (2) was formed selectively (98\%) (Table 2 / Entry 6). The solvent-free comparative thermal experiments carried out in the presence of $\mathrm{K}_{2} \mathrm{CO}_{3}$, without or with $5 \%$ of TEBAC, or in the presence of $\mathrm{Cs}_{2} \mathrm{CO}_{3}$ (Table 2 / Entries 7-9), led to similar results as the MW variations (Table 2 / Entries 2-4) and the maximum selectivity of the $O$-benzylated product 2 was only 63\% (Table 2 / Entry 9). The reaction times were, however, longer under conventional heating. It is worth mentioning that again the benzylation carried out in acetonitrile (in this case at its boiling point) was the most successful experiment (Table 2 / Entry 10).

In the similar MW-assisted benzylation of 2-naphthol (6) (Scheme 2, Table 3), the reactions were again $C$-selective in the presence of $\mathrm{K}_{2} \mathrm{CO}_{3}$. 2-Benzyloxynaphthalene (7) was obtained only in $8 \%$, while 1-benzyl-2-naphthol (8) in $51 \%$. A dialkylated product 9 (that was not identified further) was 


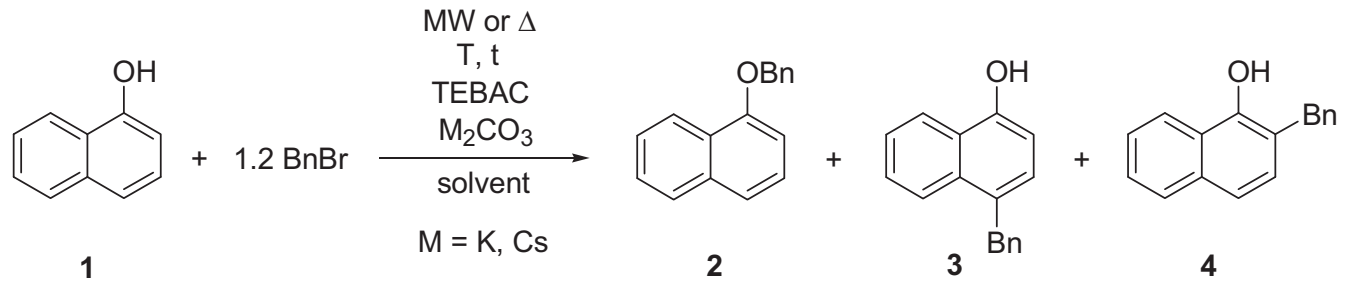

Scheme 1.

Table 2. The Benzylation of 1-Naphthol (1) with Benzyl Bromide

\begin{tabular}{|c|c|c|c|c|c|c|c|c|c|c|c|}
\hline \multirow{2}{*}{$\mathrm{M}_{2} \mathrm{CO}_{3}$} & \multirow{2}{*}{$\begin{array}{l}\text { TEBAC } \\
(\mathrm{mol} \%)\end{array}$} & \multirow{2}{*}{ Solvent } & \multirow{2}{*}{ Mode of Heating } & \multirow{2}{*}{$\mathrm{T}\left({ }^{\circ} \mathbf{C}\right)$} & \multirow{2}{*}{$T(\min )$} & 1 & 2 & 3 & 4 & $5^{\mathrm{a}}$ & \multirow{2}{*}{ Entry } \\
\hline & & & & & & \multicolumn{5}{|c|}{$(\%)^{\mathrm{b}}$} & \\
\hline- & - & - & MW & 125 & 60 & 13 & 0 & 28 & 26 & 33 & 1 \\
\hline $\mathrm{K}_{2} \mathrm{CO}_{3}$ & - & - & MW & 125 & 60 & $19^{\mathrm{c}}$ & 3 & 61 & 2 & 15 & 2 \\
\hline $\mathrm{K}_{2} \mathrm{CO}_{3}$ & 5 & - & MW & 125 & 60 & $24^{\mathrm{c}}$ & 0 & 40 & 14 & 22 & 3 \\
\hline $\mathrm{Cs}_{2} \mathrm{CO}_{3}$ & - & - & MW & 125 & 60 & $9^{c}$ & 62 & 16 & 0 & 13 & 4 \\
\hline $\mathrm{Cs}_{2} \mathrm{CO}_{3}$ & 5 & - & MW & 125 & 60 & $11^{\mathrm{c}}$ & 68 & 5 & 3 & 13 & 5 \\
\hline $\mathrm{K}_{2} \mathrm{CO}_{3}$ & - & $\mathrm{MeCN}$ & MW & 125 & 20 & 0 & $98(91)^{d}$ & 0 & 0 & 4 & 6 \\
\hline $\mathrm{K}_{2} \mathrm{CO}_{3}$ & - & - & $\Delta$ & 125 & 90 & $20^{\mathrm{c}}$ & 12 & 47 & 2 & 19 & 7 \\
\hline $\mathrm{K}_{2} \mathrm{CO}_{3}$ & 5 & - & $\Delta$ & 125 & 90 & $16^{\mathrm{c}}$ & 0 & 34 & 19 & 31 & 8 \\
\hline $\mathrm{Cs}_{2} \mathrm{CO}_{3}$ & - & - & $\Delta$ & 125 & 90 & $9^{c}$ & 63 & 11 & 0 & 17 & 9 \\
\hline $\mathrm{K}_{2} \mathrm{CO}_{3}$ & - & $\mathrm{MeCN}$ & $\Delta$ & 82 & 90 & 0 & 98 & 0 & 0 & 2 & 10 \\
\hline
\end{tabular}

${ }^{\mathrm{a}}$ Dialkylated products 5

${ }^{\mathrm{b}} \mathrm{On}$ the basis of GC.

${ }^{\mathrm{c}}$ There is no change on further irradiation/ heating.

${ }^{\mathrm{d}}$ Isolated yield.

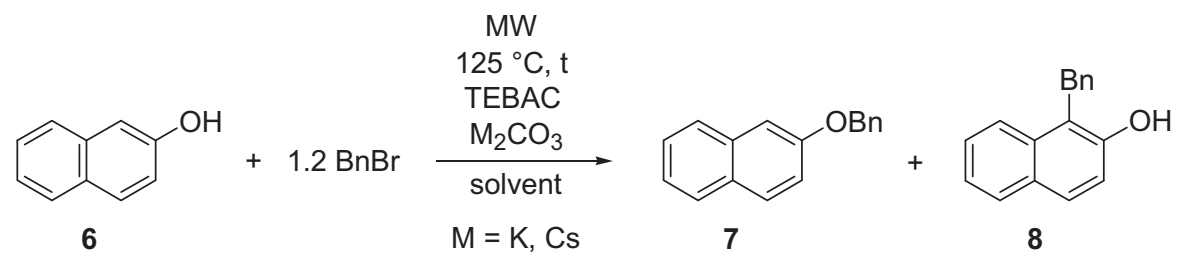

Scheme 2 .

also present in $35 \%$ (Table 3 / Entry 1 ). In the presence of 5 mol $\%$ of TEBAC, the proportion of products 7 and 8 was $0 \%$ and $80 \%$, respectively (Table $\mathbf{3}$ / Entry 2). Beyond this surprising observation it is also noteworthy that, in contrast to the benzylation of 1-naphthol (1), that of 2-naphthol (6) was not $O$-selective at all in the presence of $\mathrm{Cs}_{2} \mathrm{CO}_{3}$.

At $125{ }^{\circ} \mathrm{C}$, the ratio of products 6-9 was $6 \%, 25 \%, 30 \%$ and $39 \%$, respectively (Table 3 / Entry 3 ). However, in this case, the presence of the catalyst was somewhat beneficial as resulted in $45 \%$ of 2-benzyloxynaphthalene (7) (Table 3 / Entry 4). Again the benzylation carried out in acetonitrile as the solvent at $125{ }^{\circ} \mathrm{C}$ for $20 \mathrm{~min}$ led to the best results. In this case, the desired $O$-alkylated product 7 was formed in 89\% (Table 3 / Entry 5).

1-Naphthol (1) was then alkylated with ethyl iodide at $125^{\circ} \mathrm{C}$ under MW conditions (Scheme 3, Table 4). The reaction was in all cases $O$-selective. In the solvent-free series using $\mathrm{K}_{2} \mathrm{CO}_{3}$ or $\mathrm{Cs}_{2} \mathrm{CO}_{3}$ as the base, the proportion of 1 ethoxynaphthalene (10a), 4-ethyl-1-naphthol (11a) and dialkylated product 12a (that was not identified further) was 76$17-7 \%$ and 86-0-14\%, respectively (Table 4 / Entries 1 and $3)$. The presence of $5 \%$ of TEBAC increased the proportion of ether 10a to $94 \%\left(\mathrm{~K}_{2} \mathrm{CO}_{3}\right)$ and $95 \%\left(\mathrm{Cs}_{2} \mathrm{CO}_{3}\right)$ (Table 4 / Entries 2 and 4). In the latter case, the reaction time became shorter $(30 \mathrm{~min})$. Ethylation at $125^{\circ} \mathrm{C}$ in acetonitrile (in a closed vial) in the presence of base furnished product 10a in a selectivity of $100 \%$ (Table 4 / Entry 5 ).

Ethylation of 2-naphthol (6) (Scheme 4) led to similar results (Table 5 / Entries 1-3). Using 5\% of TEBAC in the presence of $\mathrm{K}_{2} \mathrm{CO}_{3}$ and $\mathrm{Cs}_{2} \mathrm{CO}_{3}$, the proportion of 2ethoxynaphthalene (13a) was $90 \%$ and $92 \%$, respectively (Table 5 / Entries 1 and 2). In acetonitrile, the alkylation was almost completely selective (97\%) (Table 5 / Entry 3). 
Table 3. The Benzylation of 2-Naphthol (6) with Benzyl Bromide under MW Conditions

\begin{tabular}{|c|c|c|c|c|c|c|c|c|}
\hline \multirow{2}{*}{$\mathrm{M}_{2} \mathrm{CO}_{3}$} & \multirow{2}{*}{$\begin{array}{l}\text { TEBAC } \\
(\mathrm{mol} \%)\end{array}$} & \multirow{2}{*}{ Solvent } & \multirow{2}{*}{$\mathbf{T}(\mathrm{min})$} & 6 & 7 & 8 & $9^{\mathrm{a}}$ & \multirow{2}{*}{ Entry } \\
\hline & & & & \multicolumn{4}{|c|}{$(\%)^{b}$} & \\
\hline $\mathrm{K}_{2} \mathrm{CO}_{3}$ & - & - & 60 & $6^{c}$ & 8 & 51 & 35 & 1 \\
\hline $\mathrm{K}_{2} \mathrm{CO}_{3}$ & 5 & - & 60 & $11^{\mathrm{c}}$ & 0 & $80(70)^{\mathrm{d}}$ & 9 & 2 \\
\hline $\mathrm{Cs}_{2} \mathrm{CO}_{3}$ & - & - & 60 & $6^{c}$ & 25 & 30 & 39 & 3 \\
\hline $\mathrm{Cs}_{2} \mathrm{CO}_{3}$ & 5 & - & 60 & $4^{c}$ & 45 & 13 & 38 & 4 \\
\hline $\mathrm{K}_{2} \mathrm{CO}_{3}$ & - & $\mathrm{MeCN}$ & 20 & 0 & $89(81)^{d}$ & 0 & 11 & 5 \\
\hline
\end{tabular}

${ }^{\mathrm{a}}$ Dialkylated products 9 .

${ }^{\mathrm{b}} \mathrm{On}$ the basis of GC.

${ }^{c}$ There is no change on further irradiation.

dsolated yield.

Table 4. The Alkylation of 1-Naphthol (1) with Alkyl Halides under MW Conditions

\begin{tabular}{|c|c|c|c|c|c|c|c|c|c|}
\hline \multirow{2}{*}{$\mathbf{R}$} & \multirow{2}{*}{$\mathrm{M}_{2} \mathrm{CO}_{3}$} & \multirow{2}{*}{$\begin{array}{l}\text { TEBAC } \\
(\mathrm{mol} \%)\end{array}$} & \multirow{2}{*}{ Solvent } & \multirow{2}{*}{$\mathbf{T}(\mathrm{min})$} & 1 & 10 & 11 & $12^{\mathrm{a}}$ & \multirow{2}{*}{ Entry } \\
\hline & & & & & \multicolumn{4}{|c|}{$(\%)^{b}$} & \\
\hline Et (a) & $\mathrm{K}_{2} \mathrm{CO}_{3}$ & - & - & 60 & 0 & 76 & 17 & 7 & 1 \\
\hline Et (a) & $\mathrm{K}_{2} \mathrm{CO}_{3}$ & 5 & - & 60 & 0 & 94 & 3 & 3 & 2 \\
\hline Et (a) & $\mathrm{Cs}_{2} \mathrm{CO}_{3}$ & - & - & 60 & 0 & 86 & 0 & 14 & 3 \\
\hline Et (a) & $\mathrm{Cs}_{2} \mathrm{CO}_{3}$ & 5 & - & 30 & 0 & 95 & 0 & 5 & 4 \\
\hline Et (a) & $\mathrm{K}_{2} \mathrm{CO}_{3}$ & - & $\mathrm{MeCN}$ & 30 & 0 & $100(90)^{\mathrm{c}}$ & 0 & 0 & 5 \\
\hline${ }^{n} \mathrm{Bu}(\mathbf{b})$ & $\mathrm{K}_{2} \mathrm{CO}_{3}$ & 5 & - & 60 & 2 & 91 & 0 & 7 & 6 \\
\hline${ }^{n} \mathrm{Bu}(\mathbf{b})$ & $\mathrm{Cs}_{2} \mathrm{CO}_{3}$ & 5 & - & 60 & 3 & 90 & 0 & 7 & 7 \\
\hline${ }^{n} \mathrm{Bu}$ (b) & $\mathrm{K}_{2} \mathrm{CO}_{3}$ & - & $\mathrm{MeCN}$ & 30 & 1 & $99(93)^{\mathrm{c}}$ & 0 & 0 & 8 \\
\hline${ }^{i} \operatorname{Pr}(\mathbf{c})$ & $\mathrm{K}_{2} \mathrm{CO}_{3}$ & - & $\mathrm{MeCN}$ & 120 & $13^{\mathrm{d}}$ & $87(81)^{c}$ & 0 & 0 & 9 \\
\hline
\end{tabular}

adialkylated products 12

${ }^{\mathrm{b}} \mathrm{On}$ the basis of GC.

${ }^{\mathrm{c}}$ Isolated yield.

${ }^{\mathrm{d}}$ There is no change on further irradiation.

Table 5. The Alkylation of 2-Naphthol (6) with Alkyl Halides under MW Conditions

\begin{tabular}{|c|c|c|c|c|c|c|c|c|}
\hline \multirow{2}{*}{$\mathbf{R}$} & \multirow{2}{*}{$\mathrm{M}_{2} \mathrm{CO}_{3}$} & \multirow{2}{*}{$\begin{array}{l}\text { TEBAC } \\
(\mathrm{mol} \%)\end{array}$} & \multirow{2}{*}{ Solvent } & 6 & 13 & 14 & $15^{\mathrm{a}}$ & \multirow{2}{*}{ Entry } \\
\hline & & & & \multicolumn{4}{|c|}{$(\%)^{\mathrm{b}}$} & \\
\hline Et (a) & $\mathrm{K}_{2} \mathrm{CO}_{3}$ & 5 & - & 0 & 90 & 0 & 10 & 1 \\
\hline Et (a) & $\mathrm{Cs}_{2} \mathrm{CO}_{3}$ & 5 & - & 0 & 92 & 0 & 8 & 2 \\
\hline Et (a) & $\mathrm{K}_{2} \mathrm{CO}_{3}$ & - & $\mathrm{MeCN}$ & 0 & $97(90)^{\mathrm{c}}$ & 0 & 3 & 3 \\
\hline $\mathrm{Bu}(\mathbf{b})$ & $\mathrm{K}_{2} \mathrm{CO}_{3}$ & 5 & - & 4 & 84 & 4 & 8 & 4 \\
\hline $\mathrm{Bu}(\mathbf{b})$ & $\mathrm{K}_{2} \mathrm{CO}_{3}$ & - & $\mathrm{MeCN}$ & 0 & $100(95)^{\mathrm{c}}$ & 0 & 0 & 5 \\
\hline
\end{tabular}

${ }^{\mathrm{a} D i a l k y l a t e d ~ p r o d u c t s ~} \mathbf{1 5}$.

${ }^{\mathrm{b}} \mathrm{On}$ the basis of GC.

${ }^{\mathrm{c}}$ Isolated yield.

The alkylation of 1-naphthol (1) and 2-naphthol (6) with butyl bromide (Schemes $\mathbf{3}$ and 4) was quite similar to that with ethyl iodide and resulted in 1-butoxynaphthalene (10b) and 2-butoxynaphthalene (13b) as the major products. The
$O$-selectivity was, however, somewhat lower (Table 4 / Entries 6 and 7 and Table 5 / Entry 4). The accomplishments in the presence of acetonitrile as the solvent were again very efficient (Table 4 / Entry 8 and Table 5 / Entry 5). In the 


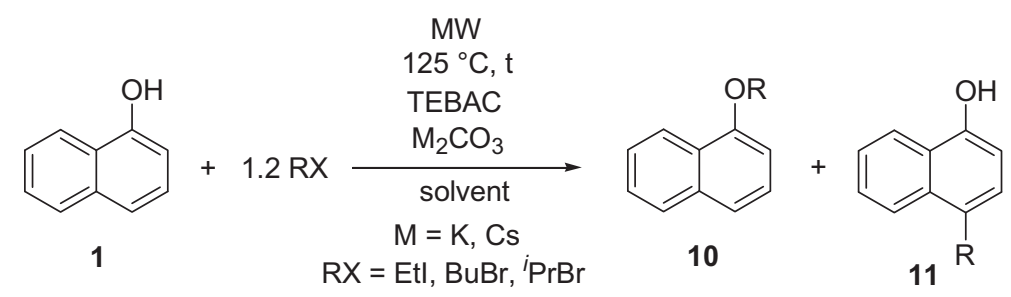

$\mathrm{R}=\mathrm{Et}(\mathbf{a}), \mathrm{Bu}(\mathbf{b}),{ }^{i} \operatorname{Pr}(\mathbf{c})$

Scheme 3.

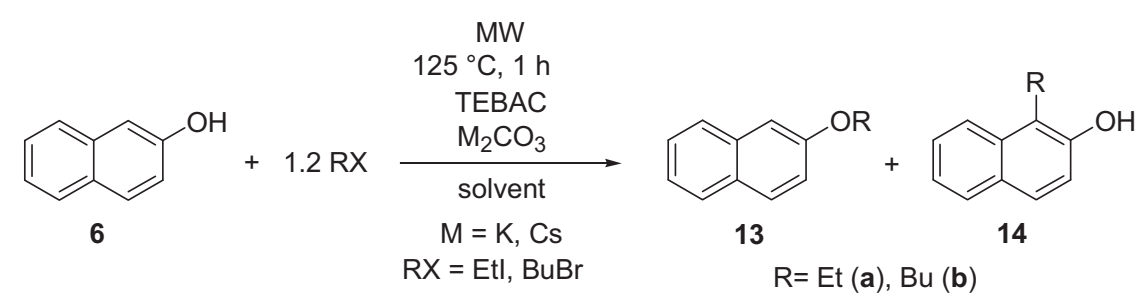

Scheme 4.

Table 6. HRMS Data for the Dialkylated by Products

\begin{tabular}{|c|c|c|c|}
\hline Compound & Formula & {$[\mathbf{M}+\mathbf{H}]^{+}{ }_{\text {measured }}$} & {$[\mathbf{M}+\mathbf{H}]^{+}$calculated } \\
\hline \hline $\mathbf{5}$ & $\mathrm{C}_{24} \mathrm{H}_{21} \mathrm{O}$ & 325.1595 & 325.1592 \\
\hline $\mathbf{9}$ & $\mathrm{C}_{24} \mathrm{H}_{21} \mathrm{O}$ & 325.1599 & 325.1592 \\
\hline $\mathbf{1 2 a}$ & $\mathrm{C}_{14} \mathrm{H}_{17} \mathrm{O}$ & 201.1281 & 201.1279 \\
\hline $\mathbf{1 2 b}$ & $\mathrm{C}_{18} \mathrm{H}_{25} \mathrm{O}$ & 257.1909 & 257.1905 \\
\hline $\mathbf{1 5 a}$ & $\mathrm{C}_{14} \mathrm{H}_{17} \mathrm{O}$ & 201.1284 & 201.1279 \\
\hline $\mathbf{1 5 b}$ & $\mathrm{C}_{18} \mathrm{H}_{25} \mathrm{O}$ & 257.1897 & 257.1905 \\
\hline
\end{tabular}

alkylation of 1-naphthol (1) with isopropyl bromide (Scheme 3) the reaction was $O$-selective, but the conversion was only $87 \%$ after a prolonged irradiation (Table 4 / Entry 9). This experience is obviously the consequence of steric hindrance.

The alkoxynaphthalenes 2, 7, 10a-c, 13a,b, and 1-benzyl2-naphthol (8) were isolated by column chromatography from the most successful experiments as shown in (Tables 25). The products were characterized by ${ }^{13} \mathrm{C}$ and ${ }^{1} \mathrm{H}$ NMR spectral data and HRMS. Where literature data were available, spectral parameters of the products were compared with those described in the literature.

Dialkylated products $5,9,12 a, 12 b, 15 a$ and $15 b$ were present in the mixtures in variable quantities (3-39\%), mostly in small proportions. For this, these components were identified by HRMS. The data are listed in Table 6.

In summary, $O$-selective alkylations of 1 - and 2naphthols (1) and (6) could be performed under MW conditions either in the presence of $\mathrm{K}_{2} \mathrm{CO}_{3}$ in acetonitrile without any catalyst, or using $\mathrm{K}_{2} \mathrm{CO}_{3}$ or $\mathrm{Cs}_{2} \mathrm{CO}_{3}$ under solvent-free conditions, in the presence of TEBAC. The second option is useful only for alkylations with alkyl halides (e.g. ethyl iodide and butyl bromide).

\section{EXPERIMENTAL SECTION}

The alkylations were carried out in a CEM Discover MW reactor equipped with a pressure controller using 20-30 W irradiation.
GC was carried out on an HP5890 series 2 GC-FID chromatograph, using a $15 \mathrm{~m} \times 0.18 \mathrm{~mm}$ Restek, Rtx-5 column with a film layer of $0.20 \mu \mathrm{m}$. The temperature of the column was initially held at $40{ }^{\circ} \mathrm{C}$ for $1 \mathrm{~min}$, followed by programming at $25{ }^{\circ} \mathrm{C} / \mathrm{min}$ up to $300{ }^{\circ} \mathrm{C}$, and a final period at $300{ }^{\circ} \mathrm{C}$ (isothermal) for $10 \mathrm{~min}$. The temperature of the injector was $290{ }^{\circ} \mathrm{C}$, and that of the FID detector $300{ }^{\circ} \mathrm{C}$. The carrier gas was $\mathrm{H}_{2}$.

GC-MS was also carried out on an Agilent 6890 N-GC5973 N-MSD chromatograph, using a $30 \mathrm{~m} \times 0.25 \mathrm{~mm}$ Restek, Rtx-5SILMS column with a film layer of $0.25 \mu \mathrm{m}$. The initial temperature of column was $45^{\circ} \mathrm{C}$ for $1 \mathrm{~min}$, followed by programming at $10{ }^{\circ} \mathrm{C} / \mathrm{min}$ up to $310{ }^{\circ} \mathrm{C}$ and a final period at $310{ }^{\circ} \mathrm{C}$ (isothermal) for $17 \mathrm{~min}$. The temperature of the injector was $250{ }^{\circ} \mathrm{C}$. The carrier gas was $\mathrm{He}$ and the operation mode was splitless.

Mass spectra were obtained using a Q-TOF Premier mass spectrometer in positive electrospray mode.

${ }^{13} \mathrm{C}$ and ${ }^{1} \mathrm{H}$ NMR spectra were obtained in $\mathrm{CDCl}_{3}$ solution on a Bruker AV-300 spectrometer operating at 75.5 and $300 \mathrm{MHz}$, respectively. Chemical shifts are downfield relative to $85 \% \mathrm{H}_{3} \mathrm{PO}_{4}$ and TMS.

General Procedure for S-L Phase Alkylation of 1- and 2Naphthol (1) and (6) under Solventless and MW Conditions

A mixture of $0.14 \mathrm{~g}(1.0 \mathrm{mmol})$ of 1- and 2-naphthol (1) and (6), in most cases $1.0 \mathrm{mmol}$ of alkali carbonate $(0.14 \mathrm{~g}$ 
of $\mathrm{K}_{2} \mathrm{CO}_{3}$ or $0.33 \mathrm{~g}$ of $\left.\mathrm{Cs}_{2} \mathrm{CO}_{3}\right)$, in certain cases $11.4 \mathrm{mg}$ $(0.05 \mathrm{mmol})$ of TEBAC and $1.2 \mathrm{mmol}$ of alkyl halide $(0.14$ $\mathrm{ml}$ of benzyl bromide, $0.10 \mathrm{ml}$ of ethyl iodide, $0.12 \mathrm{~mol}$ of butyl bromide or $0.11 \mathrm{ml}$ of $i$-propyl bromide) in a closed vial was irradiated $(20-30 \mathrm{~W})$ in a CEM Discover [300 W] MW reactor at $125^{\circ} \mathrm{C}$ for the appropriate time. The reaction mixture was taken up in $25 \mathrm{ml}$ of ethyl acetate and the suspension was filtered. Evaporation of the volatile components provided the crude product that was passed through a thin (ca. 2-3 cm) layer of silica gel using ethyl acetate as the eluant to give an oil that was analysed by GC-MS or GC.

Similar reactions were carried out in $3 \mathrm{ml}$ of $\mathrm{MeCN}$ as the solvent. The work-up was similar to that described for the solventless alkylations above, but in this case, ethyl acetate did not have to be added.

The major components of the above reactions, such as compounds 2, 7, 8, 10a-c and 13a,b were obtained in a pure form by repeated chromatography.

Control experiments were performed with benzyl bromide in a similar way under conventional heating.

1-Benzyloxynaphthalene (2) was prepared from the experiment marked by Table 2 / Entry 6 . Yield: $91 \% ;{ }^{1} \mathrm{H}$ NMR: ઈ $5.26\left(\mathrm{~s}, 2 \mathrm{H}, \mathrm{CH}_{2}\right), 6.88-6.91(\mathrm{~m}, 1 \mathrm{H}, \mathrm{ArH}), 7.32-7.56(\mathrm{~m}$, 9H, ArH), 7.78-7.83 (m, 1H, ArH), 8.32-8.37 (m, 1H, ArH); $\delta[33]\left(\mathrm{CDCl}_{3}\right) 5.23(\mathrm{~s}, 2 \mathrm{H}), 6.85-6.88(\mathrm{~m}, 1 \mathrm{H}), 7.32-7.53$ $(\mathrm{m}, \quad 9 \mathrm{H}), \quad 7.77-7.80 \quad(\mathrm{~m}, 1 \mathrm{H}), \quad 8.32-8.36 \quad(\mathrm{~m}, 1 \mathrm{H})$; $[\mathrm{M}+\mathrm{Na}]_{\text {found }}^{+}=257.0941, \mathrm{C}_{17} \mathrm{H}_{14} \mathrm{ONa}$ requires 257.0942 .

4-Benzyl-1-naphthol (3) [34] was identified from the crude product of the experiment marked by Table $\mathbf{2}$ / Entry 2. $[\mathrm{M}+\mathrm{Na}]_{\text {found }}^{+}=257.0938, \mathrm{C}_{17} \mathrm{H}_{14} \mathrm{ONa}$ requires 257.0942 .

2-Benzyloxynaphthalene (7) was prepared from the experiment marked by Table 3 / Entry 5. Yield: $81 \%$. ${ }^{1} \mathrm{H}$ NMR: ס $5.22\left(\mathrm{~s}, 2 \mathrm{H}, \mathrm{CH}_{2}\right), 7.20-7.29(\mathrm{~m}, 2 \mathrm{H}, \mathrm{ArH}), 7.33-7.59(\mathrm{~m}$, 7H, ArH), 7.72-7.87 (m, 3H, ArH); $\delta[33]\left(\mathrm{CDCl}_{3}\right) 5.17(\mathrm{~s}$, 2H, $\left.\mathrm{CH}_{2}\right), 7.21-7.23(\mathrm{~m}, 2 \mathrm{H}), 7.30-7.49(\mathrm{~m}, 7 \mathrm{H}), 7.70-7.77$ $(\mathrm{m}, 3 \mathrm{H})(\mathrm{ArH}) .[\mathrm{M}+\mathrm{Na}]_{\text {found }}^{+}=257.0947, \mathrm{C}_{17} \mathrm{H}_{14} \mathrm{ONa}$ requires 257.0942.

1-Benzyl-2-naphthol (8) prepared from the experiment marked by Table $\mathbf{3}$ / Entry 2. Yield: $70 \% .{ }^{13} \mathrm{C}$ NMR: $\delta 30.8$ $\left(\mathrm{CH}_{2}\right), 117.9\left(\mathrm{C}_{3}\right), 118.2\left(\mathrm{C}_{1}\right), 123.3\left(\mathrm{C}_{7}\right),{ }^{\mathrm{a}} 123.4\left(\mathrm{C}_{9}\right),{ }^{\mathrm{a}} 126.2$ $\left(\mathrm{C}_{4}{ }\right),{ }^{\mathrm{b}} 126.7\left(\mathrm{C}_{8}\right),{ }^{\mathrm{b}} 128.3\left(\mathrm{C}_{2},{ }^{\mathrm{c}}{ }^{\mathrm{c}} 128.6\left(\mathrm{C}_{4}\right.\right.$ and $\left.\mathrm{C}_{6}\right), 128.7$ $\left(\mathrm{C}_{3}{ }\right){ }^{\mathrm{c}}{ }^{\mathrm{c}} 129.6\left(\mathrm{C}_{5}\right), 133.7\left(\mathrm{C}_{10}\right), 140.0\left(\mathrm{C}_{1}\right), 151.2\left(\mathrm{C}_{2}\right)\left[\mathrm{C}_{1}\right.$, $\mathrm{C}_{2}, \mathrm{C}_{3}$, and $\mathrm{C}_{4}$ ' means the $\mathrm{C}_{\alpha}, \mathrm{C}_{\beta}, \mathrm{C}_{\gamma}$ and $\mathrm{C}_{\delta}$ carbon atoms in the phenyl ring], ${ }^{\mathrm{a}-\mathrm{c}}$ may be reversed; $\delta[35]\left(\mathrm{CDCl}_{3}\right) 31.11$, $118.31,118.58,123.68,123.78,126.58,127.13,128.64$, $128.97,128.99,129.02,129.90,134.09,140.40$ and 151.61. ${ }^{1} \mathrm{H}$ NMR: $\delta 4.49\left(\mathrm{~s}, 2 \mathrm{H}, \mathrm{CH}_{2}\right), 4.95(\mathrm{~s}, 1 \mathrm{H}, \mathrm{OH}), 7.14(\mathrm{~d}, J=$ $8.8 \mathrm{~Hz}, 1 \mathrm{H}, \mathrm{ArH}), 7.18-7.32(\mathrm{~m}, 5 \mathrm{H}, \mathrm{ArH}), 7.37(\mathrm{t}, J=7.0$ $\mathrm{Hz}, 1 \mathrm{H}, \mathrm{ArH}), 7.47$ (t, $J=7.1 \mathrm{~Hz}, 1 \mathrm{H}, \mathrm{ArH}), 7.75(\mathrm{~d}, J=8.8$ $\mathrm{Hz}, 1 \mathrm{H}, \mathrm{ArH}), 7.83$ (d, $J=8.0 \mathrm{~Hz}, 1 \mathrm{H}, \mathrm{ArH}), 7.95$ (d, $J=8.5$ $\mathrm{Hz}, 1 \mathrm{H}, \mathrm{ArH}) ; \delta[35]\left(\mathrm{CDCl}_{3}\right) 4.50\left(\mathrm{~s}, 2 \mathrm{H}, \mathrm{CH}_{2}\right), 7.05-7.24$ (m, 5H, ArH), 7.28-7.50 (m, 2H, ArH), $7.74(\mathrm{~d}, J=9.0 \mathrm{~Hz}$, $1 \mathrm{H}, \mathrm{ArH}), 7.84(\mathrm{~d}, J=8.1 \mathrm{~Hz}, 1 \mathrm{H}, \mathrm{ArH}), 7.94-7.97(\mathrm{~m}, 2 \mathrm{H}$, $\mathrm{ArH}) ;[\mathrm{M}+\mathrm{Na}]_{\text {found }}^{+}=257.0947, \quad \mathrm{C}_{17} \mathrm{H}_{14} \mathrm{ONa}$ requires 257.0942 .

1-Ethoxynaphthalene (10a) was prepared from the experiment marked by Table 4 / Entry 5. Yield: $96 \% .{ }^{13} \mathrm{C}$ NMR: $\delta 14.8\left(\mathrm{CH}_{3}\right), 63.7\left(\mathrm{CH}_{2}\right), 104.6\left(\mathrm{C}_{2}\right), 120.0\left(\mathrm{C}_{4}\right){ }^{\mathrm{a}}{ }^{\mathrm{a}}$
$122.1\left(\mathrm{C}_{9}\right),{ }^{\mathrm{a}} 125.0\left(\mathrm{C}_{8}\right),{ }^{\mathrm{b}} 125.7\left(\mathrm{C}_{10}\right), 125.9\left(\mathrm{C}_{3}\right),{ }^{\mathrm{b}} 126.3$ $\left(\mathrm{C}_{7}\right),{ }^{\mathrm{b}} 127.4\left(\mathrm{C}_{6}\right),{ }^{\mathrm{b}} 134.5\left(\mathrm{C}_{5}\right), 154.7\left(\mathrm{C}_{1}\right)^{\mathrm{a}, \mathrm{b}}$ tentative assignment. ${ }^{1} \mathrm{H}$ NMR: $\delta 1.58\left(\mathrm{t}, J=7.0 \mathrm{~Hz}, 3 \mathrm{H}, \mathrm{CH}_{3}\right), 4.23(\mathrm{q}, J=$ $\left.7.0 \mathrm{~Hz}, 2 \mathrm{H}, \mathrm{CH}_{2}\right), 6.83(\mathrm{~d}, J=7.5 \mathrm{~Hz}, 1 \mathrm{H}, \mathrm{ArH}), 7.37-7,54$ (m, 4H, ArH), 7.80-7.85 (m, 1H, ArH), 8.32-8.36 (m, 1H, $\mathrm{ArH}) ;[\mathrm{M}+\mathrm{Na}]^{+}$found $=195.0790, \mathrm{C}_{12} \mathrm{H}_{12} \mathrm{ONa}$ requires 195.0786.

1-Butoxynaphthalene (10b) was prepared from the experiment marked by Table $\mathbf{4}$ / Entry 8 . Yield: $93 \%$. ${ }^{1} \mathrm{H}$ NMR: $\delta 1.12\left(\mathrm{t}, J=7.4 \mathrm{~Hz}, 3 \mathrm{H}, \mathrm{CH}_{3}\right), 1.61-1.78\left(\mathrm{~m}, 2 \mathrm{H}, \mathrm{CH}_{2}\right)$, $1.92-2.06\left(\mathrm{~m}, 2 \mathrm{H}, \mathrm{CH}_{2}\right), 4.20\left(\mathrm{t}, J=6.3 \mathrm{~Hz}, 2 \mathrm{H}, \mathrm{OCH}_{2}\right)$, $6.88(\mathrm{~d}, J=7.2 \mathrm{~Hz} 1 \mathrm{H}, \mathrm{ArH}), 7.40-7.63$ (m, 4H, ArH), 7.84$7.92(\mathrm{~m}, 1 \mathrm{H}, \mathrm{ArH}), 8.38-8.46\left(\mathrm{~m}, 1 \mathrm{H}, \mathrm{ArH} ; \delta[30]\left(\mathrm{CDCl}_{3}\right)\right.$ $1.05\left(\mathrm{t}, J=7.3 \mathrm{~Hz}, 3 \mathrm{H}, \mathrm{CH}_{3}\right), 1.63\left(\mathrm{~m}, 2 \mathrm{H}, \mathrm{CH}_{2}\right), 1.93(\mathrm{~m}$, $\left.2 \mathrm{H}, \mathrm{CH}_{2}\right), 4.12\left(\mathrm{t}, J=6.3 \mathrm{~Hz}, 2 \mathrm{H}, \mathrm{OCH}_{2}\right), 6.82(\mathrm{~m}, 1 \mathrm{H}), 7.41$ $(\mathrm{m}, 4 \mathrm{H}), 7.81(\mathrm{~m}, 1 \mathrm{H}), 8.32(\mathrm{~m}, 1 \mathrm{H})(\mathrm{ArH}) ;[\mathrm{M}+\mathrm{Na}]^{+}$found $=$ 223.1104, $\mathrm{C}_{14} \mathrm{H}_{16} \mathrm{ONa}$ requires 223.1099.

1-Isopropoxynaphthalene (10c) prepared from the experiment marked by Table 4 / Entry 9. Yield: $81 \% .{ }^{13} \mathrm{C}$ NMR: $\delta 22.1\left(\mathrm{CH}_{3}\right), 70.3(\mathrm{CH}), 103.3\left(\mathrm{C}_{2}\right), 119.8\left(\mathrm{C}_{4}\right),{ }^{\mathrm{a}}$ $122.3\left(\mathrm{C}_{9}\right),{ }^{\mathrm{a}} 124.9\left(\mathrm{C}_{8}\right),{ }^{\mathrm{b}} 125.8\left(\mathrm{C}_{3}\right),{ }^{\mathrm{b}} 126.2\left(\mathrm{C}_{7}\right),{ }^{\mathrm{b}} 126.5$ $\left(\mathrm{C}_{10}\right), 127.4\left(\mathrm{C}_{6}\right),{ }^{\mathrm{b}} 134.7\left(\mathrm{C}_{5}\right), 153.6\left(\mathrm{C}_{1}\right){ }^{\mathrm{a}, \mathrm{b}}$ tentative assigment. ${ }^{1} \mathrm{H}$ NMR: $\delta 1.49\left(\mathrm{t}, J=6.1 \mathrm{~Hz}, 6 \mathrm{H}, \mathrm{CH}_{3}\right), 4.73-4.82$ $(\mathrm{m}, 1 \mathrm{H}, \mathrm{ArH}), 6.87$ (d, $J=7.4 \mathrm{~Hz}, 1 \mathrm{H}, \mathrm{ArH}), 7.38-7,54(\mathrm{~m}$, 4H, ArH), 7.80-7.85 (m, 1H, ArH), 8.31-8.36 (m, 1H, ArH; $[\mathrm{M}+\mathrm{Na}]_{\text {found }}^{+}=209.0947, \mathrm{C}_{13} \mathrm{H}_{14} \mathrm{ONa}$ requires 209.0942 .

2-Ethoxynaphthalene (13a) was prepared from the experiment marked by Table 5 / Entry 3. Yield: 90\%. ${ }^{1} \mathrm{H}$ NMR: $\delta 1.50\left(\mathrm{t}, J=7.0 \mathrm{~Hz}, 3 \mathrm{H}, \mathrm{CH}_{3}\right), 4.17(\mathrm{q}, J=7.0 \mathrm{~Hz}, 2 \mathrm{H}$, $\mathrm{CH}_{2}$ ), 7.11-2.20 (m, 2H, ArH), 7.30-7.38 (m, 1H, ArH), 7.40-7.49 (m, 1H, ArH), 7.69-7.81 (m, 3H, ArH); $\delta[30]$ $\left(\mathrm{CDCl}_{3}\right) 1.50(\mathrm{t}, J=6.6 \mathrm{~Hz}, 3 \mathrm{H}), 4.14(\mathrm{q}, J=6.6 \mathrm{~Hz}, 2 \mathrm{H})$, $7.14(\mathrm{~m}, 2 \mathrm{H}), 7.33(\mathrm{~m}, 1 \mathrm{H}), 7.41(\mathrm{~m}, 1 \mathrm{H}), 7.74(\mathrm{~m}, 3 \mathrm{H})$; $[\mathrm{M}+\mathrm{Na}]^{+}$found $=195.0788, \mathrm{C}_{12} \mathrm{H}_{12} \mathrm{ONa}$ requires 195.0786 .

2-Butoxynaphthalene (13b) was prepared from the experiment marked by Table $\mathbf{5}$ / Entry 5. Yield: 95\%. ${ }^{1} \mathrm{H}$ NMR: $\delta 1.05\left(\mathrm{t}, J=7.4 \mathrm{~Hz}, 3 \mathrm{H}, \mathrm{CH}_{3}\right), 1.54-1.63\left(\mathrm{~m}, 2 \mathrm{H}, \mathrm{CH}_{2}\right)$, $1.84-1.91\left(\mathrm{~m}, 2 \mathrm{H}, \mathrm{CH}_{2}\right), 4.11\left(\mathrm{t}, J=6.5 \mathrm{~Hz}, 2 \mathrm{H}, \mathrm{OCH}_{2}\right)$, 7.16-7.22 (m, 2H, ArH), 7.34-7.39 (m, 1H, ArH), 7.44-7.49 (m, 1H, ArH), 7.74-7.82 (m, 3H, ArH); $\delta[30]\left(\mathrm{CDCl}_{3}\right) 1.02$ $\left(\mathrm{t}, J=7.4 \mathrm{~Hz}, 3 \mathrm{H}, \mathrm{CH}_{3}\right), 1.55\left(\mathrm{~m}, 2 \mathrm{H}, \mathrm{CH}_{2}\right), 1.85(\mathrm{~m}, 2 \mathrm{H}$, $\left.\mathrm{CH}_{2}\right), 4.09\left(\mathrm{t}, J=6.5 \mathrm{~Hz}, 2 \mathrm{H}, \mathrm{OCH}_{2}\right), 7.16(\mathrm{~m}, 2 \mathrm{H}), 7.33(\mathrm{~m}$, $1 \mathrm{H}), 7.44(\mathrm{~m}, 1 \mathrm{H}), 7.76(\mathrm{~m}, 3 \mathrm{H})(\mathrm{ArH}) ;[\mathrm{M}+\mathrm{Na}]^{+}$found $=$ $223.1100, \mathrm{C}_{14} \mathrm{H}_{16} \mathrm{ONa}$ requires 223.1099.

\section{CONFLICT OF INTEREST}

The author(s) confirm that this article content has no conflict of interest.

\section{ACKNOWLEDGEMENTS}

The above project was supported by the Hungarian Scientific and Research Fund (OTKA No K83118).

\section{REFERENCES}

[1] Deshayes, S.; Liagre, M.; Loupy, A.; Luche, J.-L.; Petit, A. Microwave activation in phase transfer catalysis. Tetrahedron, 1999, 55, 10851-10870. 
[2] Keglevich, G.; Grün, A.; Bálint E. Microwave Irradiation and Phase Transfer Catalysis in C-, O- and N-Alkylation. Curr. Org. Synth. in press.

[3] Keglevich, G.; Novák, T.; Vida, L.; Greiner, I. Microwave irradiation as an alternative to phase transfer catalysis in the liquidsolid phase, solvent-free C-alkylation of active methylene containing substrates. Green Chem., 2006, 8, 1073-1075.

[4] Keglevich, G.; Majrik, K.; Vida, L.; Greiner, I. Microwave irradiation as a green alternative to phase transfer catalysis: Solidliquid phase alkylation of active methylene containing substrates under solvent-free conditions. Lett. Org. Chem., 2008, 5, 224-228.

[5] Greiner, I.; Sypaseuth, F. D.; Grün, A.; Karsai, É.; Keglevich, G. The role of phase transfer catalysis in the microwave-assisted $N$ benzylation of amides, imides and $\mathrm{N}$-heterocycles. Lett. Org. Chem., 2009, 6, 529-534.

[6] Campbell, L. J.; Borges, L. F.; Heldrich F. J. Microwave accelerated preparation of aryl 2-(N,N-diethylamino)ethyl ethers. Bioorg. Med. Chem. Lett., 1994, 4, 2627-2630.

[7] Wang, J.-X., Zhang, M. L.; Hu, Y. L. Synthesis of 8-quinolinyl ethers under microwave irradiation. Synth. Commun., 1998, 28, 2407-2413.

[8] Bogdal, D.; Pielichowski, J.; Boroń, A. New synthetic method of aromatic ethers under microwave irradiation in dry media. Synth. Commun., 1998, 28, 3029-3039.

[9] Pchelka, B. K.; Loupy, A.; Petit, A. Improvement and simplification of synthesis of 3-aryloxy-1,2-epoxypropanes using solvent-free conditions and microwave irradiations. Relation with medium effects and reaction mechanism. Tetrahedron, 2006, 62, 10968-10979.

[10] Yadav, G. D.; Bisht, P. M. Novelties of microwave irradiated solidliquid phase transfer catalysis (MISL-PTC) in synthesis of 2'benzyloxyacetophenone. J. Mol. Catal. A-Chem., 2004, 221, 59-69.

[11] Yadav, G. D.; Bisht, P. M. Fundamental analysis of microwave irradiated liquid-liquid phase transfer catalysis (MILL-PTC): Simultaneous measurement of rate and exchange equilibrium constants in selective O-alkylation of p-text-butylphenol with benzyl chloride. J. Mol. Catal. A-Chem., 2005, 236, 54-64.

[12] Mitra, A. K.; De, A.; Karchaudhuri, N. Microwave enhanced synthesis of aromatic methyl ether. Indian J. Chem., 2000, 39B, 387-389.

[13] Sarju, J.; Danks, T. N.; Wagner, G. Rapid microwave-assisted synthesis of phenyl ethers under mildly basic and nonaqueous conditions. Tetrahedron Lett., 2004, 45, 7675-7677.

[14] Peng, Y.; Song, G. Combined microwave and ultrasound assisted Williamson ether synthesis in the absence of phase-transfer catalysts. Green Chem., 2002, 4, 349-351.

[15] Keglevich, G.; Bálint, E.; Karsai, É.; Grün, A.; Bálint, M.; Greiner, I. Chemoselectivity in the microwave-assisted solvent-free solidliquid phase benzylation of phenols: O- versus C-alkylation. Tetrahedron Lett., 2008, 49, 5039-5042.

[16] Keglevich, G.; Bálint, E.; Karsai, É.; Varga, J.; Grün, A.; Bálint, M.; Greiner, I. Heterogeneous phase alkylation of phenols making use of phase transfer catalysis and microwave irradiation. Lett. Org. Chem., 2009, 6, 535-539.

[17] Bálint, E.; Greiner, I.; Keglevich, G. Microwave-assisted alkylation of phenols by quaternary onium salts. Lett. Org. Chem., 2011, 8 , $22-27$.
[18] Upender, V.; Pollart, D. J.; Liu, J.; Hobbs, P. D.; Olsen, C.; Chao, W.; Bowden, B.; Crase, J. L.; Thomas, D. W.; Pandey, A.; Lawson, J. A.; Dawson, M. I. The synthesis and biological activity of two analogs of the anti-HIV alkaloid michellamine B. J. Heterocycl. Chem., 1996, 33, 1371-1384.

[19] Lee, J. C.; Yuk, J. Y.; Cho, S. H. Facile synthesis of alkyl phenyl ethers using cesium carbonate. Synth. Commun., 1995, 25, 13671370 .

[20] Chu, G.-H.; Witt-Enderby, P. A.; Jones, M.; Li, P.-K. Synthesis and pharmacological analysis of high affinity melatonin receptor ligands. Chem. Pharm. Bull., 2002, 50, 272-275.

[21] Dehmlow, E. V. Influence of phase transfer catalyst structure on selectivity. Russ. Chem. Bull., 1995, 44, 1998-2005.

[22] Bram, G.; Geraghty, N.; Nee, G.; Seyden-Penne, J. Regioselectivity of the alkylation of ambident anionic species on alumina or in the presence of solid hexamethylphosphoric triamide. J. Chem. Soc., Chem. Commun., 1980, 1330, 325-326.

[23] Montanari, F.; Quici, S.; Tundo, P. Mechanism of reactions promoted by polymer-supported phase-transfer catalysts. J. Org. Chem., 1983, 48, 199-202.

[24] Ghiaci, M.; Sedaghat, M. E.; Kalbasi, R. J.; Abbaspur, A. Applications of surfactant-modified clays to synthetic organic chemistry. Tetrahedron, 2005, 61, 5529-5534.

[25] Cafeo, G.; Kohnke, F. H.; Valenti, L. Regioselective O-alkylations and acylations of polyphenolic substrates using a calix[4]pyrrole derivative. Tetrahedron Lett., 2009, 50, 4138-4140.

[26] Zadmard, R.; Aghapoor, K.; Bolourtchian, M.; Saidi, M. R. Solid composite copper-copper chloride assisted alkylation of naphthols promoted by microwave irradiation. Synth. Commun., 1998, 28, 4495-4499.

[27] Yadav, G. D.; Bisht, P. M. Synergism of low energy microwave irradiation and solid-liquid phase transfer catalysis for selective alkylation of phenols to phenolic ethers. Synth. Commun., 2004, 34, 2885.

[28] Earle, M. J.; McCormac, P. B.; Seddon, K. R. Regioselective alkylation in ionic liquids. Chem. Commun., 1998, 2245-2246.

[29] Xu, Z. Y.; Q., X. D.; Liu, B. Y. Williamson reactions in ionic liquids. Org. Prep. Proced. Int., 2004, 36, 156.

[30] Cazorla, C.; Pfordt, É.; Duclos, M.; Métay, E.; Lemaire, M. OAlkylation of phenol derivatives via a nucleophilic substitution. Green Chem., 2011, 13, 2482-2488.

[31] Maras, N.; Polanc, S.; Kocevar, M. Synthesis of aryl alkyl ethers by alkylation of phenols with quaternary ammonium salts. Acta Chimica Slovenica, 2010, 57, 29-36.

[32] Maraš, N.; Polanc, S.; Kočevar, M. Microwave-assisted methylation of phenols with tetramethylammonium chloride in the presence of $\mathrm{K}_{2} \mathrm{CO}_{3}$ or $\mathrm{Cs}_{2} \mathrm{CO}_{3}$. Tetrahedron, 2008, 64, 1161811624.

[33] Shintou, T.; Mukaiyama, T. Efficient methods for the preparation of alkyl-aryl and symmetrical or unsymmetrical dialkyl ethers between alcohols and phenols or two alcohols by oxidationreduction condensation. J. Am. Chem. Soc., 2004, 126, 7359-7367.

[34] Gu, W.; Weiss, R. G. Mediation of photochemical reactions of 1naphthyl phenylacylates by polyolefin films. A 'radical clock' to measure rates of radical-pair cage recombinations in 'viscous space'. Tetrahedron, 2000, 56, 6913-6925.

[35] Nawal, K. P.; Lindsay, D.; Amitabh, J. Convenient synthesis of 1arylmethyl-2-naphthols. Synth. Commun., 2007, 37, 877-888. 